\title{
SOSIALISASI IMPLEMENTASI PEDOMAN AKUNTANSI PESANTREN BERBASIS DIGITAL PADA PESANTREN DI INDONESIA
}

\author{
Citra Sukmadilaga ${ }^{1}$, Lastuti Abu Bakar², Tri Handayani ${ }^{3}$, Yusar Sagara ${ }^{4}$, \\ Ifa Hanafiah Sejiati ${ }^{5}$, dan Tri Utami Lestari ${ }^{6}$ \\ ${ }^{123}$ Universitas Padjadjaran \\ ${ }^{4}$ UIN Syarif Hidayatullah \\ ${ }^{5}$ Universitas Islam Bandung \\ ${ }^{6}$ Universitas Telkom \\ E-mail: citra.sukmadilaga@unpad.ac.id
}

\begin{abstract}
ABSTRAK. Tujuan dilakukannya pelatihan akuntansi Pesantren membantu mewujudkan pesantren yang transparan, akuntabel, partisipatif, tertib dan disiplin keuangan serta menambah pengetahuan pengelola pesantren betapa pentingnya peranan akuntansi pesantren dalam rangka akuntabilitas publik Metode penelitian ini dilakukan dengan Focus Group Discussion yang dihadiri oleh 38 orang pengelola keuangan pesantren yang tersebar di wilayah Kalimantan, Jawa Barat, Jawa Tengah. Hasil yang diperoleh adalah akuntansi pesantren masih sangat sulit untuk diimplementasikan karena pesantren pada umumnya bersifat tertutup, terpusat dan kekeluargaan. Terutama jika menyangkut persoalan keuangan, hanya kiyai dan keluarganyalah yang mempunyai kewenangan. Selain itu, banyak pesantren yang tidak memisahkan antara harta kekayaan pesantren dengan pemilik pesantren. Walaupun disadari bahwa pembiayaan pesantren justru lebih banyak bersumber dari kekayaan pemilik sebab sumber-sumber lain penopang pesantren kurang memadai. Terdapat beberapa faktor yang berperan dalam kesuksesan implementasi akuntansi pesantren yaitu manajemen sebagai faktor upaya, organisasi sebagai faktor Sarana, dan administrasi sebagai faktor Karsa. Ketiga faktor ini memberi arah dan perpaduan dalam merumuskan, mengendalikan penyelenggaraan, mengawasi serta menilai pelaksanaan kebijakan-kebijakan dalam usaha menyelenggarakan akuntansi yang sesuai dengan tujuan Pondok Pesantren masing-masing.
\end{abstract}

Kata kunci: Pedoman Akuntansi Pesantren; Akuntansi Digital; Akuntansi Pesantren; Sosialisasi.

ABSTRACT. The aim of Accounting fo pesantren training is to improve transparent, accountable, participatory, orderly, and financial discipline as well as increasing the knowledge of pesantren managers who facilitate the application of Accounting fo pesantren in the framework of public accountability. This research method was conducted with a Focus Group Discussion which was attended by 38 financial managers spread across the Kalimantan, West Java and Central Java regions. The result indicated that accounting for pesantren is still very difficult to implement because pesantren are generally protected, centralized and familial. More when it comes to finance, only the clerics and their families that have authority. In addition, many pesantren do not separate the assets of the pesantren from the owners of the pesantren. Although it is realized that pesantren funding comes mostly from the owner's wealth, because other sources of support for the pesantren are inadequate. There are several factors related to the implementation of accounting for pesantren, namely management as an effort factor, organization as a facility factor, and administration as an intention factor. These three factors provide direction and integration in formulating, controlling, regulating, and approving policies in an effort to regulate accounting in accordance with the objectives of each Islamic boarding school.

Keywords: Pesantren Accounting Guidelines; Digital Accounting; Accounting for Pesantren; Socialization

\section{PENDAHULUAN}

Pondok pesantren merupakan sebuah lembaga pendidikan tertua di Indonesia. Pendidikan ini pada awalnya merupakan pendidikan agama Islam yang dimulai sejak munculnya masyarakat Islam pada abad ke-13 (Usman, 2013). Beberapa abad kemudian, muncul tempat pengajian yang merupakan tempat warga atau masyarakat yang ingin mengkaji agama Islam. Kemudian, dengan disediakannya tempat menginap bagi masyarakat yang ingin mengkaji agama Islam, maka, tempat pengajian tersebut disebut sebagai pesantren (A. Steenbrink, 1989). Memasuki era modern ini, pondok pesantren diharapkan menjadi agen perubahan dan pembangunan masyarakat dengan tidak hanya memainkan fungsi-fungsi tradisionalnya yakni: pertama, Pendidikan dan transfer ilmu-ilmu Islam; kedua, pemeliharaan tradisi Islam; dan ketiga, reproduksi ulama (Azra, 2003; Yasmadi, 2002;
Siradj, 1999, Jabal, 2002 dan Maksum, 2003). Azra (2000) mengatakan bahwa, selain memainkan ketiga fungsi tradisional tadi, pesantren juga dijadikan sebagai pusat penyuluhan kesehatan; pusat pengembangan teknologi tepat guna bagi masyarakat pedesaan; pusat usaha-usaha penyelamatan dan pelestarian lingkungan hidup; dan lebih penting lagi menjadi pusat pemberdayaan ekonomi masyarakat sekitarnya.

Dalam penyelenggaraan Pondok Pesantren, ada beberapa faktor yang berperan dalam sistem penyelenggaraan Pondok Pesantren yaitu, manajemen sebagai faktor Upaya, organisasi sebagai faktor Sarana, dan administrasi sebagai faktor karsa. Ketiga faktor ini memberi arah dan perpaduan dalam merumuskan, mengendalikan penyelenggaraan, mengawasi serta menilai pelaksanaan kebijakan-kebijakan dalam usaha menyelenggarakan kegiatan pendidikan yang sesuai dengan tujuan Pondok Pesantren masing-masing. (Arifin,2016) Menerapkan 
sistem manajemen di Pesantren bukanlah hal yang mudah. Walaupun sebagian besar orang memandang bahwa Pesantren adalah sebuah lembaga yang kuno, namun ketika coba dikelola menjadi sebuah lembaga yang profesional, ada tantangan tersendiri untuk mewujudkan pesantren yang profesional. Selama ini, banyak pihak yang menengarai bahwa salah satu kelemahan lembaga pendidikan Islam, termasuk pesantren adalah bidang manajemen. Manajemen pesantren pada umumnya bersifat tertutup, terpusat dan kekeluargaan. Lebih-lebih jika menyangkut persoalan keuangan, hanya kiyai dan keluarganyalah yang boleh mengetahuinya. Hal ini mengesankan bahwa pesantren laksana tembok berlin yang sulit ditembus oleh siapapun. (Arifin, 1993; Dhofir, 1994; Kafrawi, 1978; Rahardjo, 1985 dan Wahid, 2001).

Salah satu bagian terpenting dalam manajemen pesantren adalah pengelolaan keuangan. Dalam suatu lembaga, termasuk pesantren, pengelolaan keuangan sering menimbulkan permasalahan yang serius bila pengelolaannya kurang baik. Di pesantren, pengelolaan keuangan sebenarnya tidak begitu rumit, sebab pesantren merupakan lembaga swadana yang tidak memerlukan pertanggungjawaban keuangan yang terlalu pelik kepada penyandang dananya. Namun demikian, karena banyak juga dana yang bersumber dari masyarakat untuk mendanai pesantren, walaupun jumlahnya relatif kecil hal itu perlu ada laporan atau penjelasan sederhana sesuai dengan prinsip-prinsip pengelolaan keuangan publik kepada masyarakat agar kredibilitas pesantren dimata masyarakat cukup tinggi, disinilah perlunya pengelolaan keuangan dengan baik dan transparan dibudayakan di lingkungan pesantren. (Arifin, 2016)

Pengelolaan keuangan pesantren yang baik ini sebenarnya juga merupakan bagian dari upaya melindungi personil pengelola pesantren (kiai, ustadz/ustadzah, atau pengelola lainnya) terhadap pandangan yang kurang baik dari luar pesantren. Selama ini banyak pesantren yang tidak memisahkan antara harta kekayaan pesantren dengan individu, walaupun disadari bahwa pembiayaan pesantren justru lebih banyak bersumber dari kekayaan individu sebab sumber-sumber lain penopang pesantren kurang memadai. Namun, dalam rangka pengelolaan manajemen yang baik seharusnya ada pemilihan antara harta kekayaan pesantren dengan individu, agar dapat diketahui secara transparan oleh pihak-pihak lain, termasuk orang tua sendiri. Kita menyadari bahwa banyak di Pesantren masalah keuangan selalu menjadi kendala dalam melakukan aktivitas Pesantren, baik yang berkaitan dengan anggaran, akuntansi, penataan administrasi, alokasi serta kebutuhan pengembangan Pesantren maupun dalam proses aktivitas keseharian Pesantren. Tidak sedikit Pesantren yang memiliki sumberdaya baik manusia maupun alamnya tidak tertata dengan rapi, dan tidak sedikit pula proses pendidikan Pesantren berjalan lambat karena kesalahan dalam penataan menejemen keuangannya.
Ikatan Akuntan Indonesia dan Bank Indonesia telah menerbitkan Pedoman Akuntansi Pesantren. SAK yang digunakan sebagai acuan dalam penyusunan Pedoman Akuntansi Pesantren adalah Standar Akuntansi Keuangan Entitas Tanpa Akuntabilitas Publik (SAK ETAP). Pertimbangan dalam memilih acuan kepada SAK ETAP dilandasi bahwa aset yang dikelola Pondok Pesantren relatif besar nilainya karena sebagian besar aset Pondok Pesantren adalah Waqaf permanen berupa tanah. Format Penyajian atas laporan keuangan Pondok pesantren yang diatur dalam Pedoman Akuntansi Pondok Pesantren mengacu pada PSAK 45: Pelaporan Keuangan Entitas Nirlaba. Pedoman akuntansi pesantren ini diterapkan hanya untuk pondok pesantren yang telah berbadan hukum yayasan yaitu telah terdapat pemisahan kekayaan antara pondok pesantren dengan pemilik yayasan. Pedoman akuntansi pesantren tidak diterapkan pada badan usaha yang berbadan hukum yang dimiliki oleh pondok pesantren seperti perseroan terbatas. Format Penyajian atas laporan keuangan Pondok pesantren yang diatur dalam PAP mengaju pada PSAK 45: Pelaporan Keuangan Entitas Nirlaba. Pedoman Akuntansi Pesantren mengatur bahwa laporan keuangan lengkap yang harus disusun oleh Pondok Pesantren ada beberapa hal. Pertama laporan posisi keuangan; laporan aktivitas; laporan arus kas; dan Catatan atas laporan keuangan.

\section{METODE}

Metode yang digunakan dalam kegiatan PPM ini yaitu dengan kerja kelompok dalam kegiatan. Kegiatan KKN-PPM diawali dengan pembekalan oleh Dosen Pembimbing Lapangan (DPL) beserta rekan dan asistennya. Kegiatan KKN-PPM ini mengenai sosialisasi akuntansi pesantren dengan membawa judul "Pemberdayaan Pesantren: Transparansi dan Akuntabilitas Keuangan di Era Teknologi Informasi 4.0 Melalui Pelatihan Akuntansi Berbasis Syariah". Pembekalan ini diharapkan agar peserta KKN-PPM mampu menjalankan segala rangkaian kegiatan dengan baik dan benar saat pelaksanaan sosialisasinya. Mahasiswa di training oleh anggota peneliti selama 1 bulan (Selama bulan juli 2019) karena beberapa peserta KKN bukan berasal dari akuntansi. Training di lakukan di kampus jatinangor dan kampus Dipati Ukur.

\section{Implementasi Proses Kegiatan KKN}

Kegiatan pertama sebelum pembekalan adalah diskusi mengenai program yang akan dijalankan sekaligus perkenalan mentor-mentor oleh DPL yang akan membantu membimbing selama kegiatan KKN-PPM berlangsung.

Kegiatan diawali dengan perkenalan sistem dan penjelasan terkait akun-akun yang terdapat di dalamnya. Seperti cara membuat bisnis baru, mengubah nama, logo 
dan akun-akun lainnya yang penting untuk diketahui. Mahasiswa setelah diberi pemahaman mengenai dasar akuntansi, maka mereka mulai di training menggunakan software yang dikembangkan oleh anggota team untuk dipersiapkan menjadi pendamping pada saat sosialisasi pedoman akuntansi pesantren menggunakan software.

Pada tanggal 29 Juli 2019, kegiatan KKN-PKM yakni sosialisasi Pedoman Akuntansi Pesantren dan Pengelolaan Keuangan Pesantren Berbasis Digital dilaksanakan dengan mengundang 20 Pesantren yang telah diseleksi dari group Whatsapp yang beranggotakan 120 peserta dari berbagai pesantren di seluruh Indonesia. Pada hari $\mathrm{H}$ nya hadir 5 perwakilan pesantren dari luar daerah diantaranya Balikpapan dan makassar yang menyengaja datang untuk hadir saat pelatihan.

\section{HASIL DAN PEMBAHASAN}

\section{Pengelolaan Keuangan dan Akuntansi}

Dalam pelaksanaan pengelolaan keuangan Pondok Pesantren Kiayi merupakan otorisator penuh terhadap pengeluaran keuangan. Setiap dana yang keluar harus disetujui oleh Kiayi Pesantren, proses pelaksanaan keuangan untuk melakukan setiap kegiatan yang telah tercantum dalam anggaran harus membuat proposal kegiatan beserta rincian dana yang dibutuhkan dalam kegiatan tersebut, setelah disetujui oleh internal Audit (Kepala Sekolah) baru kemudian Kiayi Pondok Pesantren mengeluarkan uang sesuai dengan yang ada di proposal. Setiap kegiatan yang telah dilakukan langkah selanjutnya adalah membuat Laporan Pertanggungjawaban (LPJ). Membuat LPJ merupakan suatu keharusan bagi setiap bagian yang ada di lingkungan Pondok Pesantren, setiap LPJ masing-masing bagian tersebut akan diaudit oleh internal audit, dan hasilnya kemudian diserahkan kepada Kiayi Pondok Pesantren. Laporan hasil internal audit tersebut jadi bahan evaluasi bagi Kiayi Pondok Pesantren terhadap kegiatan yang telah dilakukan, apakah telah dilaksanakan sesuai dengan program perencanaan dan proposal atau sebaliknya. Adapun pengeluaran seperti gaji guru langsung diberikan kepada yang bersangkutan oleh bendahara dengan disahkan oleh Kepala Sekolah dan Kiayi Pondok Pesantren.

\section{Penerimaan atau pemasukan}

Pemasukan keuangan Pesantren dari berbagai sumber perlu dilakukan pembukuan berdasarkan prosedur yang disepakati, baik konsep teoritis maupun peraturan pemerintah. Sumbangan dana yang masuk ke Pesantren bisa kita klasifikasi sebagai dana langsung dan dana tidak langsung. Dana tidak langsung adalah dana berupa perbandingan waktu guru dan peserta dididk dalam mengunakan setiap waktunya di sekolah atau Pesantren, seperti penyesuaian waktu belajar mengajar ketika di bandingkan dengan ketika guru atau peserta didik mengunakanya untuk bekerja, dan juga perhitunganya dengan transportasi, dan biaya hidup. dana ini memang sulit sekali dihitung karena tidak ada catatan resminya. Namun dalam perencanaan biaya ini turut dihitung. Dana langsung, adalah dana yang di peroleh dari beberapa sumber yang sah.

\section{Pengeluaran}

Alokasi dari dana pendapatan Pesantren harus pula diatur secermat mungkin. Ada beberapa klasifikasi dalam pengeluaran dana yang di pakai secara umum di lembagalembaga pendidikan kita, yaitu :

a. Dana pembangunan, pengeluaran dana ini diatur dan digunakan untuk pembangunan dan pembenahan sarana fisik lembaga, dana ini di sesuaikan dengan kebutuhan dan jumlah guru serta peserta didik yang ada di lembaga pendidikan tersebut.

b. Dana rutin, dana rutin adalah dana yang digunakan untuk biaya operasional satu tahun anggaran. Dana rutin pengunaanya meliputi pelaksanaan progam belajar mengajar, pembayaran gaji guru maupun personil, serta pemeliharaan dan perawatan sarana prasarana lembaga pendidikan.

Untuk menghitung dana rutin lembaga pendidikan harus menghitung total cost atau nilai unit cost yang dibutuhkan setiap siswa atau santri. Nilai unit cost merupakan nilai satuan biaya yang dikeluarkan untuk memberikan pelayanan terhadap seorang peserta didik setiap tahun dalam satu jenjang pendidikan. Berdasarkan akutansi keuangan di Pesantren, ada beberapa hal yang harus di perhatikan oleh bendaharawan Pesantren:

a. membuat laporan keuangan kepada Pesantren dan komite Pesantren untuk di cocokan dengan rancangan anggaran Pesantren

b. menyertakan bukti-bukti laporan keuangan, termasuk bukti pembayaran pajak bila ada

c. kwitansi atau bukti-bukti pembelian dan dan penerimaan berupa tanda tangan penerima atau bukti pengeluaran yang lain

d. menunjukan neraca keuangan untuk di periksa oleh tim penangungjawaban keuangan dari yang bersangkutan.

Hal-hal yang perlu di persiapkan oleh bendaharawan Pesantren meliputi :

a. buku kas umum

b. buku persekot atau uang muka

c. daftar potongan-potongan

d. daftar honoranium

e. buku tabungan

f. buku iuran atau kontribusi santri

g. buku catatan untuk pengeluaran-pengeluaran yang tidak terduga

\section{Penggunaan Aplikasi Akuntansi Berbasis Digital}

Realitas baru akuntansi di era digital membutuhkan perbaikan permanen kompetensi seorang akuntan modern. Inti dari kompetensi tersebut adalah pengetahuan tentang terminologi akuntansi profesional, yang saat ini 
mengalami "infus" dan pembaruan yang substansial, disertai dengan perluasan konten operasi ekonomi dan munculnya pendekatan baru untuk akuntansi.

Laporan keuangan tujuan umum saat ini sedang mendapatkan dukungan. Sementara apa yang masuk ke dalam laporan keuangan tidak benar-benar berubah, bagaimana informasi disampaikan oleh laporan itu banyak berubah.

Perkembangan teknologi dalam informasi dan komunikasi meningkatkan perkembangan dalam dunia akuntansi perusahaan, salah satu yang berkembang dan umum diimplementasikan adalah Aplikasi Sistem Komputer Akuntansi atau sering disebut Software Akuntansi. Manfaat aplikasi sistem komputer akuntansi adalah

1. Mempermudah dalam menyusun laporan keuangan perusahaan dengan akurat, efisien dan cepat;

2. Kecepatan dalam mendapatkan laporan keuangan; yang dihasilkan secara otomatis oleh komputer dibandingkan dengan cara manual;

3. Memiliki tingkat ketepatan yang tinggi;

4. Mampu menghasilkan dan menampilkan lebih banyak data dengan mudah dan cepat sehingga efeisiensi dapat tercapai.

Digital Accounting telah menemukan jalannya ke dalam bahasa sehari-hari yang digunakan oleh praktisi akuntansi, Salah satu aplikasi akuntansi yang cukup mudah untuk dioperasikan adalah Manager.io. Aplikasi ini adalah perangkat lunak akuntansi gratis terlengkap di Indonesia. Aplikasi tersebut memiliki semua fitur yang dibutuhkan oleh seorang akuntan dan masih berupaya untuk menambah fitur - fitur lainnya. Aplikasi ini masih memiliki beberapa keunggulan lain, yaitu:

1. Bebas selamanya, Aplikasi ini dapat menggunakan program selamanya, menggunakan semua fitur dan memasukkan data sebanyak yang diperlukan. Tidak ada batasan waktu, tidak ada batasan penggunaan, tidak ada iklan.

2. Bekerja Offline, Semua pekerjaan Anda dapat dilakukan secara offline di desktop atau laptop Anda yang berarti Anda tidak kehilangan akses ke data atau program Anda jika Internet Anda berhenti bekerja atau tidak tersedia.

3. Lintas-platform, Ini tersedia untuk diunduh di Windows, Mac OS X dan Linux. Format basis data bersifat universal di semua sistem operasi yang berarti file akuntansi yang dibuat pada Windows dapat dengan mudah ditransfer ke Mac OS X atau Linux jika diperlukan.

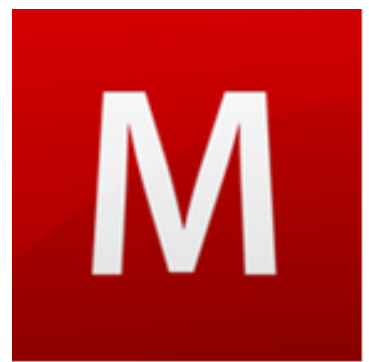

Gambar 1. Logo Manager.io

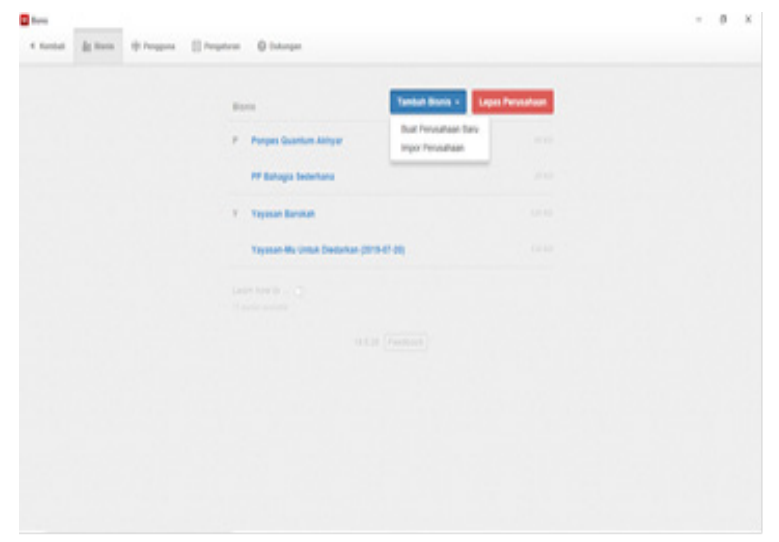

Gambar 2. Cara Membuat Bisnis Barua tau Impor Bisnis

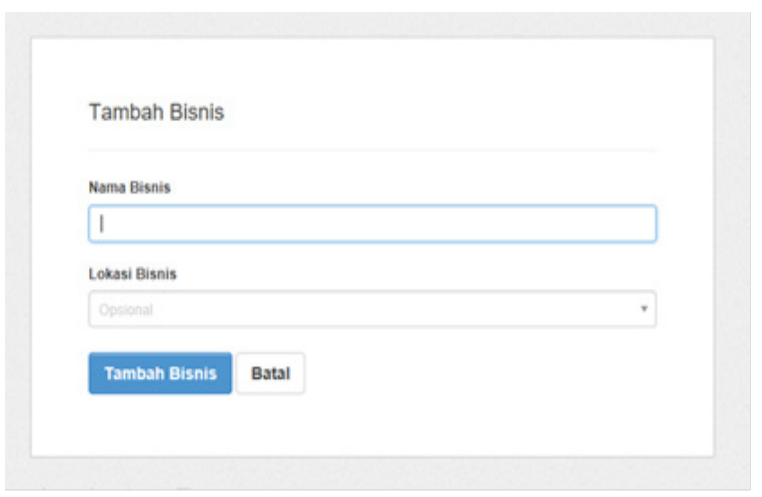

Gambar 3. Membuat Bisnis Baru

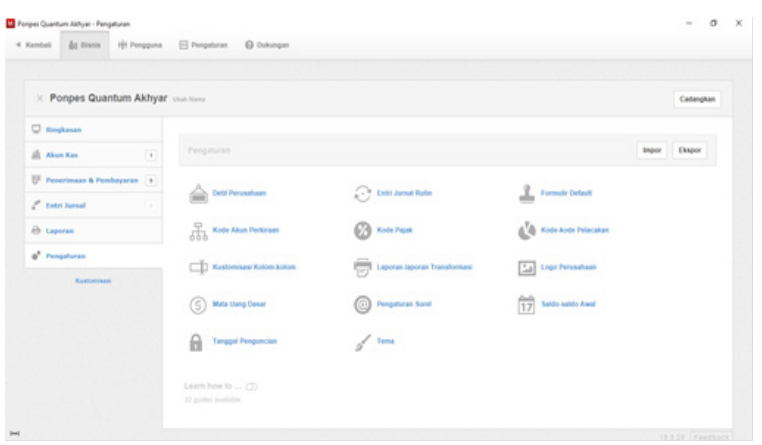

Gambar 4. Mengubah Pengaturan Perusahaan

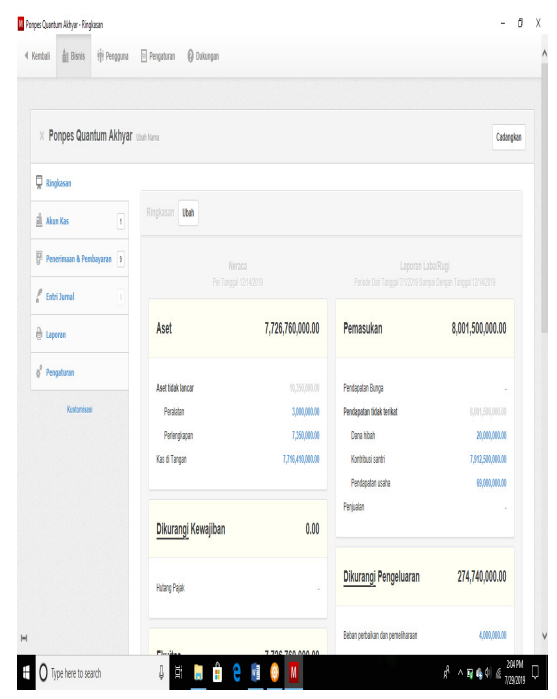

Gambar 5. Pengenalan Akun-akun dalam Sistem

Pengoperasian yang dilakukan yaitu mengentri jurnal dan arus kas berdasarkan kasus yang diberikan. 


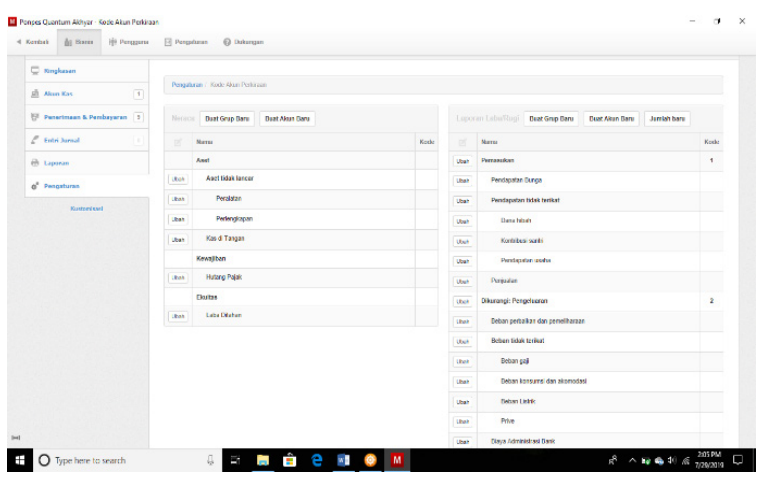

Gambar 6. Menambah dan Mengedit Akun-akun

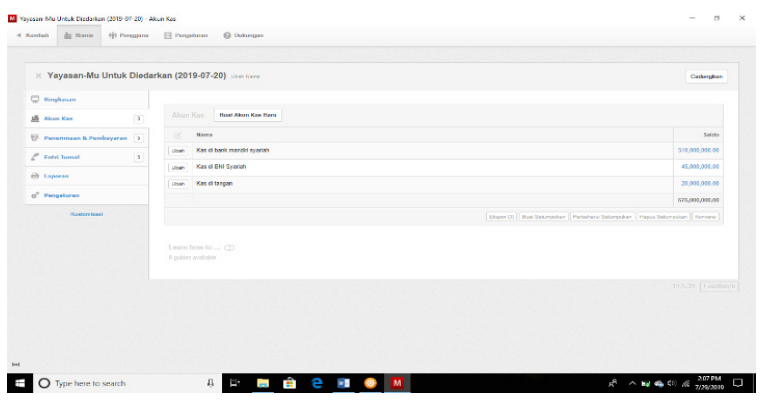

Gambar 7. Arus Kas

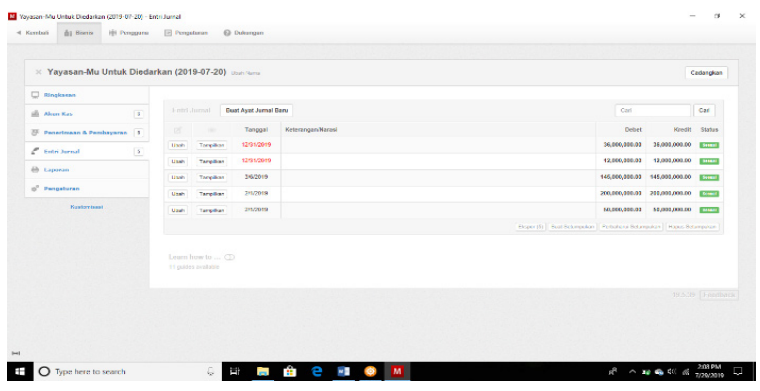

Gambar 8. Entri Jurnal

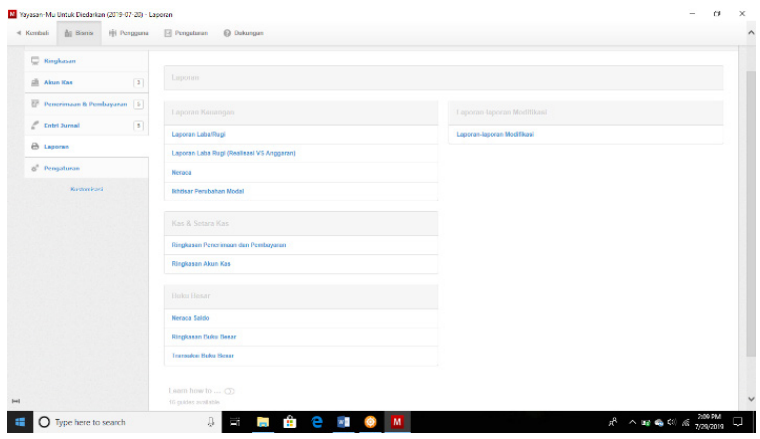

Gambar 9. Laporan-laporan dalam Sistem

\section{Analisis Situasi}

Pesantren di indonesia memiliki 2 jenis yaitu pesantren tradisional dan pesantren modren. Berdasarkan hasil observasi (tanya jawab) kegiatan pelatihan, beberapa pondok pesantren di Indonesia pun mengelola keuangan masih berbasis catat mencatat dan kurang akuntabel. Faktor yang kurang dalam mengelola keuangan pesantren yang berbasis syariah ialah belum mengikuti peraturan akuntasi terkait akuntansi pesantren.

Situasi diatas dikarenakan beberapa pengelola keuangan pesantren bukan dari bidang pengelola keuangan atau akuntansi. Beberapa pengelola keuangan secara otodidak sehingga penulisan laporan keuangan masih manual atau catat mencatat. Mengelola akun transaksi belum berbasis syariah dan akuntansi umum sehingga kurang akuntabel. Belum adanya aplikasi digital untuk pengelolaan keuangan pesantren sehingga belum memudahkan dalam membuat laporan keuangan.

Berdasarkan analisis situasi diatas, dapat disimpulkan bahwa permasalahan memiliki keterkaitan satu sama lain dalam pengelolaan keuangan pesantren.

\section{Output Kegiatan}

Pesantren merupakan lembaga atau yayasan yang menyelenggarakan kegiaan pendidikan yang berbasis agama. Pengelolaan keuangan pesantren berbasis syariah oleh karena itu pengelolaan keuangan mengikuti peraturan akutansi terkait akuntansi pesantren. Meningkatkan tingkat kepercayaan masyarakat dengan meningkatkan pengelolaan keuangan pesantren yang lebih baik (akuntabel) dan lebih transparan dengan dipermudah melalui aplikasi digital.

Output dari kegiatan KKNM dengan dilaksanakannya kegiatan Sosialisi Akuntansi Pesantren yaitu: "Pelatihan Pengelolaan Keuangan Pesantren" pada peserta pengelolaan keuangan pesantren daerah Jawa Barat hingga luar Jawa Barat.

Berdasarkan kegiatan yang telah dilaksanakan, dengan antusias, peserta yang melebihi dugaan, mengharapkan adanya kegiatan berkelanjutan mengenai program pengelolaan keuangan pesantren. Program berkelanjutan diharapkan dapat mengundang peserta pengelolaan keuangan pesantren di seluruh Indonesia sehinggan semua pondok pesantren di Indonesia diharapkan dapat mengelola keuangan secara syariah yang lebih baik .

Peserta Kegiatan sosialisasi pengelola keuangan pesantren sebanyak 20 orang peserta (Jawa Barat).

\begin{tabular}{|l|l|l|}
\hline Waktu Kegiatan & $:$ & Sabtu, 27 Juli 2019 \\
\hline Tempat & $:$ & Gedung Pertamina \\
\hline Pihak-pihak yang terlibat & $:$ & \\
\hline
\end{tabular}

\begin{tabular}{|l|l|l|l|}
\hline 1. & $\begin{array}{l}\text { Citra Sukmadilaga S.E.,M. } \\
\text { BA,Ak.Ph.D }\end{array}$ & $\begin{array}{l}\text { Ketua Tim KKNM } \\
\text { dan Pembina } \\
\text { Akuntansi pesantren }\end{array}$ \\
\hline 2. & $\begin{array}{l}\text { Yusar Sagara SE,Ak, M.Si,CA, } \\
\text { CMA,CPMA }\end{array}$ & Pembicara \\
\hline 3. & Ifa Hanifa Sejiati S.Sy.,M.Si & $:$ & Pembicara \\
\hline 4. & Dicky Arie Sandy & $:$ & Pembicara \\
\hline 5. & Divina Mahardika Dewi,S.E & $:$ & Pembicara \\
\hline 6. & Siti Fazriah,S.E & $:$ & Pembicara \\
\hline 7. & Hida Hiyanti,S.E & $:$ & Pembicara \\
\hline 8. & Tri Utami Lestari, S.E., M.Ak & $:$ & Pembicara \\
\hline 9. & Allessandra Lamuli Margaretha & $:$ & $\begin{array}{l}\text { Panitia dan } \\
\text { Fasilitator }\end{array}$ \\
\hline 10. & Ciptadi Maulana & $:$ & $\begin{array}{l}\text { Panitia dan } \\
\text { Fasilitator }\end{array}$ \\
\hline 11. & Maulia Indriana Ghani & $:$ & $\begin{array}{l}\text { Panitia dan } \\
\text { Fasilitator }\end{array}$ \\
\hline
\end{tabular}




\begin{tabular}{|c|l|c|l|}
\hline 12. & Inge Korima & $:$ & $\begin{array}{l}\text { Panitia dan } \\
\text { Fasilitator }\end{array}$ \\
\hline 13. & Ahmad Raihan Hidayat Koto & $:$ & $\begin{array}{l}\text { Panitia dan } \\
\text { Fasilitator }\end{array}$ \\
\hline 14. & Faisal Akbar & $:$ & $\begin{array}{l}\text { Panitia dan } \\
\text { Fasilitator }\end{array}$ \\
\hline 15. & Rahmansyah Ade Putra Amir & $:$ & $\begin{array}{l}\text { Panitia dan } \\
\text { Fasilitator }\end{array}$ \\
\hline 16. & Zisvira Jasni Handa Putri & $:$ & $\begin{array}{l}\text { Panitia dan } \\
\text { Fasilitator }\end{array}$ \\
\hline 17. & Alfatyani Inayah & $:$ & $\begin{array}{l}\text { Panitia dan } \\
\text { Fasilitator }\end{array}$ \\
\hline
\end{tabular}

Setelah sosialisasi pedoman akuntansi pesantren dan pelatihan pengelolaan keuangan berbasis digital selesai dilakukan, masih banyak anggota group whatsapp yang ingin ikutan sehingga tindak lanjut pelatihan tersebut dilaksanakan oleh HIMA MAKSI UNPAD beberapa waktu setelahnya

\section{SIMPULAN}

Dalam pengimplementasianya akuntansi pondok pesantren masih terkendala budaya yang telah ada dan dipraktekan secara turun menurun di pondok pesantren. Salah satu budaya yang mendominasi adalah otoritas keputusan seluruhnya dipegang oleh kyai. Dalam perjalannya pesantren tidak memisahkan antara harta kyai dengan harta milik pesantren sehingga secara prinsip entitas sejak awal memang telah sulit untuk dilaksanakan. Di pesantren dikenal dengan istilah pengelolaan keuangan yang terbatas pada pengelolaan keuangan trandisional yang dilaksanakan dengan prinsip kekeluargaan namun berdasarkan hasil diskusi diketahui bahwa pesantren telah terlebih dahulu mempraktikan pengelolaan keaungan dalam arti pembukuan yang hanya terbatas pada pencatatan uang masuk dan uang keluar. Di kebanyakan pesantren hal ini masih dilakukan secara manual yaitu mengunakan buku-buku atau catatan-catatan yang tidak terdokumentasi secara jelas sehingga akan menyulitkan pada saat dilakukan pencocokan antara catatan dan bukti. Sebagian besar pesantren menyimpan uangnya secara phisik di rumah kyai bahkan sangat jarang yang menyimpan uang nya di bank.

Pada kegiatan Pengabdian Kepada Masyarakat ini memiliki beberapa poin penting, yaitu:

1) Pondok pesantren sudah mulai banyak yang ingin belajar mengenai akuntansi, dinilai dari banyaknya partisipan baik yang sudah terdaftar maupun yang belum terdaftar untuk mengikuti pelatihan yang diadakan. Partisipan yang mengikuti pelatihan ini tidak hanya berasal dari wilayah Jawa Barat, melainkan terdapat dari wilayah Jawa Tengah hingga wilayah Kalimantan.

2) Pihak pondok pesantren sangat antusias mengikuti seluruh rangkaian yang diadakan, dimulai saat pelatihan mengenai akuntansi syariah secara manual hingga pelatihan mengenai aplikasi digital untuk tata kelola laporan keuangan. Pada kedua sesi pelatihan tersebut terdapat sesi tanya jawab dan pelatihan soal yang diikuti oleh peserta. Sesi tanya jawab berlangsung dengan cukup lama dikarenakan banyaknya pertanyaan yang diajukan oleh peserta mengenai akuntansi syariah baik secara manual maupun aplikasi digital. Setiap peserta diberikan software gratis untuk coba diterapkan di Pesantren masing-masing. Setelah mereka mempelajari pedoman akuntansi pesantren tersebut berikut software untuk pelaporan keuangan, maka diharapkan mereka dapat membuat laporan keuangan sederhana bagi pesantren mereka.

3) Panitia penyelenggara juga sangat antusias mengikuti seluruh rangkaian yang diadakan, dimulai saat pelatihan mengenai akuntansi syariah secara manual hingga pelatihan mengenai aplikasi digital untuk tata kelola laporan keuangan. Pada saat pelatihan mengenai aplikasi digital, panitia penyelenggara ikut turun langsung untuk membantu pondok pesantren yang mendapat kesulitan saat mengoperasikan aplikasi tersebut.

\section{DAFTAR PUSTAKA}

A. Steenbrink, K. (1989). Pesantren Madrasah Sekolah. Jakarta: LP3ES.

Arifin, I. (1993). Kepemimpinan Kiyai: Kasus Pondok Pesntren Tebu Ireng. Malang: Kalimasada Press.

Arifin, M. (2016). Manajemen Keuangan Pondok Pesantren, Fikrotuna. Jurnal Pendidikan dan Manajemen Islam, 4(2).

Azra, A. A. (2000). Pendidikan Islam, Tradisi, dan Modernisasi Menuju Melinium Baru. Jakarta: Logos Wacana Ilmu.

Azra, A. A. (2003). Surau, Pendidikan Islam Tradisional dalam Transisi dan Modernisasi. Jakarta: Logos Wacana Ilmu.

Azra, A. A. (2003). Surau, Pendidikan Islam Tradisional dalam Transisi dan Modernisasi. Jakarta: Logos Wacana Ilmu.

Dhofir, Z. D. (1994). Tradisi Pesantren. Jakarta: LP3ES.

Jabal, F. (2002). IAIN dan Modernisasi Islam di Indonesia. Jakarta: Logos Wacana Ilmu.

Kafrawi. (1978). Pembaharuab Sistem Pendidikan Pesantren. Jakarta: Cemara Indah.

Maksum,A.(2003). Tasawufsebagai Pembebasan Manusia Modern. Surabaya: Pustaka Pelajar dan Pusat Studi Agama, Politik, dan Masyarakat [PSAPM].

Rahardjo, D. (1985). Pergulatan Dunia Pesantren. Jakarta: LP3ES. 
Siradj, S. A., \& (et.al). (1999). Pesantren Masa Depan, Wacana Pembedayaan dan Transformasi Pesantren. Bandung: Pustaka Hidayah.

Usman, M. I. (2013). Pesantren Sebagai Lembaga Pendidikan (Sejarah Lahir, Sistem Pendidikan dan Perkembangan Masa Kini). Jurnal Al Hikmah, 14(1).
Wahid, A. W. (2001). Menggerakkan Tradisi, Esai-esai Pesantren. Yogyakarta: LKIS Yogyakarta.

Ya'cub, M. (1984). Pondok Pesantren dan Pembangunan Desa. Bandung: Angkasa.

Yasmadi. (2002). Modernisasi Pesantren: Kritikan Nurcholis Madjid terhadap Pendidikan Islam Tradisional. Jakarta: Ciputat Press. 